\title{
EXOGENOUS SPRAY OF MANGO (Mangifera indica L.) TREES WITH ANTIOXIDANT SOLUTIONS IN RELATION TO CHANGES IN FRUIT QUALITY AND STORABILITY AT HARVEST AND DURING COLD STORAGE
}

Samaan, L. G. ${ }^{1}$; E. F. A. El-Dengawy ${ }^{2}$; L. A. Arafat ${ }^{1}$ and Heba M. El- Fayoumy ${ }^{1}$

1 Pomology Department, Faculty of Agriculture, Mansoura University 2 Pomology Dept., Fac. Agric., Damietta branch, Mansoura University

\section{ABSTRACT}

The present investigation was carried out in two successive seasons of 2008 and 2009 on "Hindi" and "Zibda" fruiting trees to study the effect of pre-harvest spray, ten days prior to harvest time, with each of vitamin $C$ solution at $1.0 \mathrm{gL}^{-1} " \mathrm{~T}_{1}$ " and vitamin $\mathrm{B}_{12}$ solution at $1.0 \mathrm{mgL}^{-1}$ " $\mathrm{T}_{2}$ "along with tap water to serve as control " $\mathrm{T}_{\mathrm{c}}$ " on three fruit physical characteristics including changes on fruit firmness, weight loss $\%$ and chilling injury incidence. Moreover, six chemical characteristics in fruit juice including changes on vitamin C content, total acidity \%, total soluble solids \%, total soluble solids/acid ratio and along with $\beta$-carotene and total chlorophyll pigments in fresh peels were examined at harvest time and throughout cold storage period(30 day) at $5 \pm 1^{\circ} \mathrm{C}$ and $80-85 \% \mathrm{RH}$. The tested trees were 20 -years-old, almost uniform, apparently diseases free and grown in a commercial orchard located in Kafer Saker province, EL-Sharkia governorate, Egypt.

The concerned results of physical and chemical characteristics (except for weight loss \%) at harvest time and during cold storage period almost indicated significant differences among the tested treatments. The rate of changes differed among the tested treatments either at harvest time or throughout cold storage period. In general, pre-harvest sprayed trees of both mango cultivars with antioxidant solutions could be succeeded to improve the tested qualities of the treated fruit trees at harvest time and during cold storage period with different rates based on certain critical factors include the tested treatment, cultivar genotype and fruit characteristic under study. Antioxidant treatments also had an effect on shelf life of stored mango fruits with different rates due to the critical factors indicated above.

Cold stored fruits of "Hindi" cultivar continued under provided storage conditions till $15^{\text {th }}$ day determination without observing the incidence of chilling injury symptoms and could be extended to 20 day storage with mild symptoms. In case of "Zibda" stored fruits, they showed a similar behavior as "Hindi" fruits till 15 day storage, afterward both antioxidant treatments succeeded to store fruits till the $30^{\text {th }}$ day determination (end of storage period) with mild chilling injury symptoms. Fruits of both cultivars during these cold storage periods were of firmness and qualities acceptable to consumers.

\section{INTRODUCTION}

Mangoes (Mangifera indica L.) belong to the family Anacardiaceae are considered one of the most preferred fruits in the world due to their attractive color and fragrance, delicious taste along with excellent nutritional properties. Consequently, mangoes have prominent position among commercial fruits and considered an emerging tropical export crop in about $90 \%$ countries in 
world with total production of over 25.1 million tons (Sauco, 2002). In Egypt, Anonymous (2008) the total area occupied by mango trees reached 204,284 feddans with total production of 466,436 tons. Generally, mango fruit is a climacteric fruit harvests at the mature green stage and ripens during the marketing process with irregular storage period in warm conditions between harvest and consumption times. Difficult of quality traits for mango fruit are a short season, highly perishable and very short storage life as well as harvest fruit at an optimal maturity. Proper harvest time, pre-and post-harvest treatments, appropriate handling procedure and packaging all have a positive effect on the final market value of the produced fruits (Tasneem, 2004). Therefore, it is essential to adopt modern cultural practices that can provide high quality fruits and to define optimal post-harvest procedures.

Pre- and post-harvest procedures that minimize post-harvest fruit losses which are considerably high in most developing countries would be of great value. Antioxidants activity in fruits was confirmed since it was noticed that higher content of poly-phenols and vitamins in fruits have significant effects on scavenging free radicals. It was also observed that the antioxidant activity in fruits varies among species and cultivars (Award et al., 2001; Kondo et al., 2004). Although many experiments on antioxidants activity have been reported in apples and berries (Connor et al., 2002; Wolfe et al., 2003; Zheng and Wang, 2003), however a few are reported on tropical fruits. Therefore, the main goal of the present study is to provide fruits with additional amount of antioxidants through pre-harvest spraying fruiting trees of the tested mango fruit cultivars, "Hindi" and "Zibda" with solutions of ascorbic acid (Vitamin C) at $1.0 \mathrm{gL}^{-1}$ and vitamin $\mathrm{B}_{12}$ at $1.0 \mathrm{mgL}^{-1}$ solely 10 days prior to harvest time. The effect of such pre-harvest treatments on fruit quality at harvest time, changes in fruit quality characteristics at 5-dayintervals during cold storage period and fruit shelf life were studied.

\section{MATERIALS AND METHODS}

The present study was carried out during two successive seasons 2008 and 2009 on fruiting trees of two mango cultivars of important marketing value namely, "Hindi" and "Zibda" (Mangifera indica L.).

\section{The tested Materials}

The material used in this experiment was 18 fruiting mango trees at 20-year-old represent each of mango cultivars under study. Such trees were almost uniform, apparently diseases free and grown in a commercial orchard located in Kafer Saker province, El-Sharkia governorate, Egypt. Ten days prior to harvest time (first week of August), the tested trees were subjected to two spray treatments, and each represented as two trees in three replicates of each treatment. The control treatment was similar trees in the same orchard. The tested treatments can be described as follows:

$\mathrm{TC}_{\mathrm{C}}=$ Trees sprayed with tap water (TW) to serve as control.

$\mathrm{T}_{1}=$ Trees sprayed with ascorbic acid solution (Vitamin C)at1.0 gL ${ }^{1}$ concentration (VitC). 
$\mathrm{T}_{2}=$ Trees sprayed with Vitamin $\mathrm{B}_{12}$ solution (Cyanocobalamin) at $1.0 \mathrm{mgL}^{-1}$ concentration (Vit $\left.\mathrm{B}_{12}\right)$.

*-Tween-20 at $0.01 \%$ as a surfactant was added to all solutions.

Representative number of fruits at harvest time was picked from the treated trees of both tested cultivars, as usual for marketing, at the mature green stage (fruit shoulder is above the stem end). Such fruits were approximately uniform in shape and apparently healthy (free of visible infection symptoms). They were immediately transported to the laboratory, thoroughly washed with tap water and soap solution to reduce fruit's temperature, remove impurities and microbial load on the fruit surfaces.

\section{Storage conditions and fruit sampling}

The selected fruits were stored at low temperature $\left(5 \pm 1^{\circ} \mathrm{C}\right)$ and 80 $85 \%$ relative humidity $(\mathrm{RH})$ for storage period of 30 day. During this period samples of the stored fruits represent each treatment of both cultivars were randomly taken in three replicates at 5-day-intervals to measure changes of certain physical and chemical characteristics.

\section{A. Physical characteristics of fruits measured at harvest time and during cold storage period}

This part of experiment included the measurement of three physical characteristics carried out on intact fruits at harvest time and 5-day-intervals during cold storage period to explain the changes which happened during storage as a result of the pre-harvest treatments. These physical characteristics were as follows:

\section{$A_{1}$. Fruit firmness}

Fruit firmness was measured on two opposite sides of each fruit (two fruits in 3 replicates/treatment/cultivar) using a hand penetrometer supplemented with probe of $8.0 \mathrm{~mm}$ diameter. Each fruit was compressed $2 \%$ of its original diameter. Force in Newton (N) was recorded and the results were expressed as multiplies by 100 according to Reyes and Paull (1995).

\section{A2. Fruit weight loss \%}

Change in this characteristic was measured on five fruits in 3 replicates per treatment. The initial weight of each fruit was recorded at harvest time as well as every 5 days of storage period. Percentage of weight loss for each fruit was calculated in relation to its original weight. Results were represented for each treatment as average weight loss $\%$ of the tested fruits.

\section{$A_{3}$. Chilling injury $(\mathrm{Cl})$ incidence}

The visible symptoms of chilling injury "Cl" were measured on 15 fruits (3 replicates, 5 fruits each) from each treatment by the method adopted by Chaplin et al., (1991). This method depends on fruit formed a batch (skin browning) is considered to have "Cl". Chilling injury was defined as number of injured Fruits/total fruits tested. The calculated "Cl" index was based on the percentage of batch surface area and scaled according to GonzalezAguilar et al., (2001) which was divided into 5 successive levels of chilling injury severity as follows:

$1=$ no injury (NI); $2=$ light injury (LI) $(<5 \%$ of skin area affected); $3=$ moderate injury (MI) $(6-25 \%$ of skin area affected); $4=$ severe injury (SI) $(26-50 \%$ of 
skin area affected) and $5=$ very severe injury (VSI) $(>50 \%$ of skin area affected)

\section{B. Fruit chemical characteristics determined at harvest time and during cold storage period}

This part of the study is dealing with six fruit chemical characteristics determined on the juice of treated fruit and peels at harvest time and their changes at 5-day-intervals during storage period.

\section{$B_{1}$. Ascorbic acid content (Vitamin $C$ ) in fruit juice}

Ascorbic acid content (Vitamin C) in fruit juice was determined in three replicates per treatment, $2.0 \mathrm{ml}$ each adopting the procedure described by Ranganna (1979) which is based on the oxidation of ascorbic acid with 2,6 dichlorophenolendophenol dye. The obtained results were expressed as $\mathrm{mg} / 100 \mathrm{ml}$ juice recorded as an average value per treatment per cultivar at 5day-periodicals.

\section{$B_{2}$. Total acidity percentage in fruit juice}

Total acidity \% in fruit juice was determined in three replicates/ treatment, $2.0 \mathrm{ml}$ each, by titrating against $0.1 \mathrm{~N}$ sodium hydroxide $(\mathrm{NaOH})$ in the presence of phenolphthalein as an indicator (Ranganna, 1979). The obtained results were recorded as an average value/treatment/cultivar at 5day-periodicals.

\section{$B_{3}$. Total soluble solids percentage (TSS \%) in fruit juice}

It was determined by the use of an Abbe hand refractometer (AOAC, 1985 ) in three replicates per treatment, $2.0 \mathrm{ml}$ each. The obtained results were recorded as an average value per treatment per cultivar at 5-dayperiodicals.

\section{$B_{4}$. Total soluble solids/acid ratio in fruit juice}

This ratio was calculated from the values recorded for fruit juice TSS\% and total acidity \%.

\section{$B_{5}$. Pigment contents in fruit fresh peels}

Pigments content in fruit fresh peels as total chlorophylls and $\beta$ carotene were determined. Peel samples of the treatments $(0.5 \mathrm{~g})$ were prepared and extracted in $10 \mathrm{ml}$ of $\mathrm{N}, \mathrm{N}$-dimethyl Formamide (DMF) in the dark for at least $48 \mathrm{hr}$. The extracts were centrifuged for $5 \mathrm{~min}$ at $6000 \mathrm{rpm}$ to take supernatant after removal of any suspended material. The absorbance in supernatant was read by UV-Vis spectrophotometer at wave length of 664, 647 and $442 \mathrm{~nm}$. The obtained readings used to calculate total chlorophyll and $\beta$-carotene contents in fresh peels according to the equations designed by Moran (1982). The obtained results were expressed as $\mu \mathrm{g} / \mathrm{g}$ fresh peel and recorded as an average value per treatment per cultivar at 5-dayperiodicals.

\section{Statistical analysis}

The experiment in the 2 tested seasons was laid out in 2-Factorial design. The obtained data were subjected to analysis of variance (ANOVA) and the treatment means were separated by F-test and the least significant difference (L.S.D) test at the $5 \%$ level using the statistical package SAS (1996). 


\section{RESULTS AND DISCUSSION}

According to the great similarity among the obtained results in the two tested seasons of the present study (2008 and 2009), they were reviewed and discussed as an average of both seasons.

\section{A. Effect of pre-harvest antioxidant treatments on three fruit physical characteristics at harvest time and during cold storage period}

Firmness is considered one of the main quality attributes in fruit for consumer acceptability. Fruit softening is directly related to the rate of degradation of pectin substances and hemicelluloses through enzymatic hydrolysis of cellular components during ripening and over storage time. This in turn results in weakening of cell walls and the cohesive forces that bind cells together (Heyes et al., 1994 and Kajuna et al., 1997)

Post-harvest management of mangoes firmness due to pre-harvest sprays with antioxidant solutions was cleared from the concerned results in Table (1). Such results proved that changes in fruit firmness at harvest time and during storage period were differed according to the tested treatment. At harvest time, fruits of the cultivar "Hindi" from trees pre-harvest sprayed with vitamin $C$ solution at $1.0 \mathrm{gL}^{-1}$ " $\mathrm{T}_{1}$ "significantly measured the highest firmness with an average value $20.16 \mathrm{~N} / \mathrm{Cm}^{2}$. The next effect was to either vitamin $B_{12}$ treatment " $\mathrm{T}_{2}$ " with 18.35 or " $\mathrm{T}_{\mathrm{c}}$ " one with $18.36 \mathrm{~N} / \mathrm{Cm}^{2}$ firmness average values. As for the cultivar "Zibda" a similar behavior to that of "Hindi" cultivar was observed, since at harvest time the higher firmness average value relatively was resulted in fruits from trees under vitamin C treatment (19.30 $\mathrm{N} / \mathrm{Cm}^{2}$ ). Concerning the effects of the other two treatments, they were also relatively the next in that respect with insignificant difference between them (18.46 and $18.53 \mathrm{~N} / \mathrm{Cm}^{2}$ for " $\mathrm{T}_{2}$ " and " $\mathrm{T}_{\mathrm{c}}$ ", respectively). Consequently, it could be concluded that the super effect on fruits of both mango cultivars under study was to vitamin $\mathrm{C}$ treatment " $\mathrm{T}_{1}$ " in the two tested seasons.

The periodical measurements during cold storage period revealed a gradual decrease in fruits firmness of both cultivars as the storage period advanced. Such decrease in fruits from trees under $T_{c}, T_{1}$ and $T_{2}$ treatments starting from harvest time to the end of storage period, respectively, ranged from 18.36 to $7.55 ; 20.16$ to 11.33 and 18.35 to $11.09 \mathrm{~N} / \mathrm{Cm}^{2}$ for "Hindi" stored fruits. The corresponding average ranges for "Zibda" stored fruits, respectively were from 18.53 to $7.40,19.30$ to 10.48 and 18.46 to $10.16 \mathrm{~N} / \mathrm{Cm}^{2}$. Accordingly, the highest significant decrease on fruit firmness at the end of storage period was on stored fruits from the control trees since they recorded the least average values 7.55 and $7.40 \mathrm{~N} / \mathrm{Cm}^{2}$ for "Hindi" and "Zibda" cultivars, respectively. Whereas the least decrease in that respect was on cold stored fruits from trees pre-harvest sprayed with vitamin $\mathrm{C}$ at $1.0 \mathrm{gL}^{-1}$ " $\mathrm{T}_{1}$ ". At the end of cold storage period, both treatments $\left(T_{1} \& T_{2}\right)$ had significantly an increase on fruit firmness comparing with the control one. The $\mathrm{T}_{1}$ achieved at the end of cold storage period significantly the highest average values 11.33 and $10.48 \mathrm{~N} / \mathrm{Cm}^{2}$ for "Hindi" and "Zibda" cultivars, respectively. As for the effect of " $\mathrm{T}_{2}$ " treatment, it was very similar to that of " $\mathrm{T}_{1}$ " one with insignificant difference between them $\left(11.09\right.$ and $10.16 \mathrm{~N} / \mathrm{Cm}^{2}$, respectively). 
Table (1): Effect of pre-harvest spray of mango trees cultivars Hindi and Zibda with 2 various antioxidant solutions on changes in fruits firmness at harvest time (0) and 5-day-intervals during cold storage period at $5 \pm 1^{\circ} \mathrm{C}$ for 30 days.

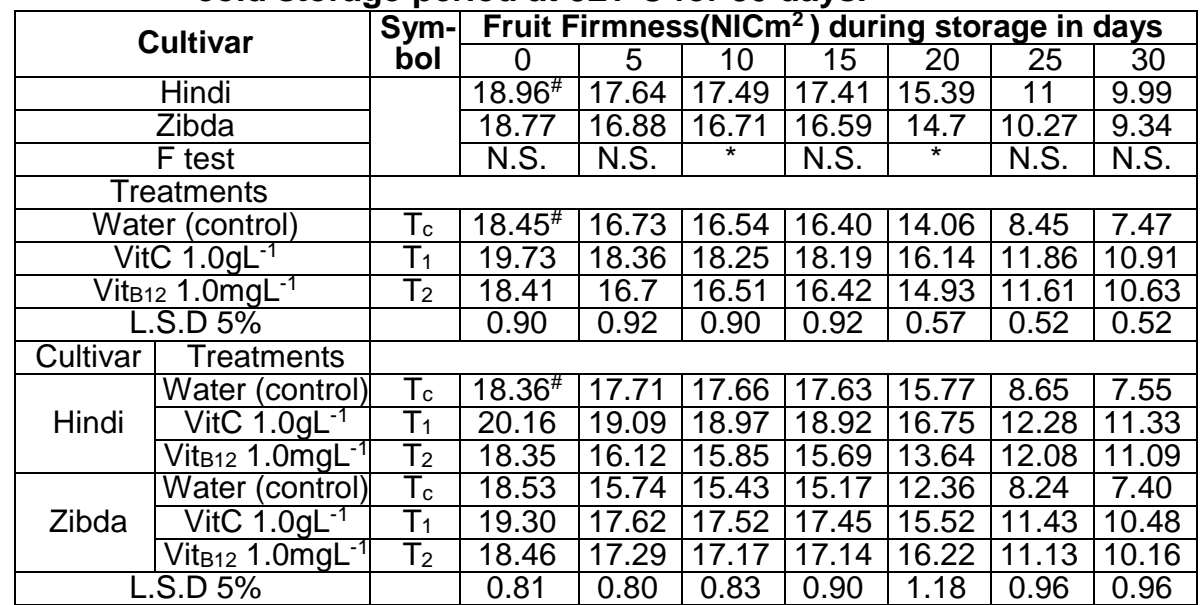

\# These values represent the average results of 2008 and 2009 seasons.

\section{A2. Changes in fruit weight loss percentage}

Changes in fruit weight loss is attributed to the physiological loss in weight due to the different rates of respiration, transpiration of water through peel tissue and other biological changes taking place in the fruit (Rathore et al., 2007). Post-harvest researchers are known to study water loss processes, since these changes may affect fruit physiology during ripening and earlier ethylene synthesis or cause a rise in membrane deterioration (Ben-Yehoshua et al., 1983 and Paull, 1999). In case of mango fruits, Peter et al., (2007) attributed the physiological loss in weight to the fact, skin bears stomata and transpiration continues after the fruit has been harvested, also reported that a maximum rise in water loss occur in the senescence stage due to degenerative changes of the skin.

The concerned results in Table (2) indicated that fruit weight loss\% during storage period significantly was not affected with either mango cultivar or treatments tested. The periodical measurements in the same table also revealed that the values of this characteristic in fruits of the two tested mango cultivars, under pre-harvest antioxidant treatments were increased as storage period advanced. At harvest time, fruits of the cultivar "Hindi" from trees of control treatment " $\mathrm{T}_{\mathrm{c}}$ " recorded the highest weight $(281.62 \mathrm{~g})$ as an average value of both seasons. The next average value was in fruits of vitamin $B_{12}$ treatment " $\mathrm{T}_{2}$ " (233.36g), whereas the least one was resulted in fruits from trees pre-harvest sprayed with vitamin $\mathrm{C}$ solution at $1.0 \mathrm{gL}^{-1}$ " $\mathrm{T}_{1}$ " with the average value $231.70 \mathrm{~g}$. As for the cultivar "Zibda", the superiority in both seasons of study, was to fruits harvested from trees of " $\mathrm{T}_{1}$ " treatment. Such fruits weighted the highest average value $(360.38 \mathrm{~g})$ followed by those from trees " $\mathrm{T}_{2}$ " treatment with the average value $335.30 \mathrm{~g}$, whereas the 
Table (2): Effect of pre-harvest spray of mango trees cultivars Hindi and Zibda with 2 various antioxidant solutions on changes in fruits weight loss percentage at harvest time (0) and 5-dayintervals during cold storage period at $5 \pm 1^{\circ} \mathrm{C}$ for 30 days.

\begin{tabular}{|c|c|c|c|c|c|c|c|c|c|}
\hline \multirow{2}{*}{\multicolumn{2}{|c|}{ Cultivar }} & \multirow[t]{2}{*}{$\begin{array}{c}\text { Sym- } \\
\text { bol }\end{array}$} & \multirow{2}{*}{\begin{tabular}{|c|}
$\begin{array}{c}\text { Fruit } \\
\text { weight (g) }\end{array}$ \\
$\mathbf{0}$
\end{tabular}} & \multicolumn{6}{|c|}{$\begin{array}{l}\text { Fruit weight loss percentage during } \\
\text { storage in days }\end{array}$} \\
\hline & & & & 5 & 10 & 15 & 20 & 25 & 30 \\
\hline \multicolumn{2}{|r|}{ Hindi } & & $248.89^{*}$ & $1.29^{\#}$ & 2.08 & 3.36 & 4.71 & 5.90 & 7.01 \\
\hline \multicolumn{2}{|r|}{ Zibda } & & 333.11 & 1.17 & 2.16 & 3.39 & 4.30 & 5.36 & 6.79 \\
\hline \multicolumn{2}{|r|}{$\mathrm{F}$ test } & & ** & N.S. & N.S. & N.S. & N.S. & N.S. & N.S. \\
\hline \multicolumn{10}{|c|}{ Treatments } \\
\hline \multicolumn{2}{|c|}{ Water (control) } & $T_{c}$ & $292.64^{*}$ & $1.06^{\#}$ & 2.07 & 3.25 & 4.31 & 5.53 & 6.69 \\
\hline \multicolumn{2}{|c|}{ VitC $1.0 \mathrm{gL}^{-1}$} & $\mathrm{~T}_{1}$ & 296.04 & 1.55 & 2.32 & 3.67 & 4.73 & 5.61 & 6.95 \\
\hline \multicolumn{2}{|c|}{$V_{\text {Vit } 12} 1.0 \mathrm{mgL}^{-1}$} & $T_{2}$ & 284.33 & 1.08 & 1.98 & 3.20 & 4.48 & 5.74 & 7.05 \\
\hline \multicolumn{2}{|c|}{ L.S.D 5\% } & & 40.68 & 0.21 & 0.21 & 0.34 & 0.73 & 1.14 & 1.08 \\
\hline Cultivar & Treatments & & & & & & & & \\
\hline \multirow{3}{*}{ Hindi } & Water (control) & $\mathrm{T}_{\mathrm{c}}$ & $281.62^{*}$ & $1.04^{\#}$ & 2.00 & 3.15 & 4.60 & 6.03 & 7.02 \\
\hline & VitC $1.0 \mathrm{gL}^{-1}$ & $\mathrm{~T}_{1}$ & 231.70 & 1.70 & 2.37 & 3.83 & 5.02 & 5.68 & 7.13 \\
\hline & Vit$_{\mathrm{B} 12} 1.0 \mathrm{mgL}^{-1}$ & $T_{2}$ & 233.36 & 1.13 & 1.88 & 3.08 & 4.52 & 5.98 & 6.87 \\
\hline \multirow{3}{*}{ Zibda } & Water (control) & $\mathrm{T}_{\mathrm{c}}$ & 303.67 & 1.08 & 2.13 & 3.35 & 4.02 & 5.03 & 6.37 \\
\hline & VitC $1.0 \mathrm{gL}^{-1}$ & $\mathrm{~T}_{1}$ & 360.38 & 1.40 & 2.27 & 3.50 & 4.43 & 5.53 & 6.77 \\
\hline & Vit$_{\mathrm{B} 12} 1.0 \mathrm{mgL}^{-1}$ & $\mathrm{~T}_{2}$ & 335.30 & 1.03 & 2.07 & 3.32 & 4.45 & 5.50 & 7.23 \\
\hline \multicolumn{2}{|c|}{ L.S.D 5\% } & & 32.29 & 0.17 & 0.47 & 0.53 & 0.64 & 1.05 & 1.06 \\
\hline
\end{tabular}

*These values represent the average results of fruit weight in 2008 and 2009 seasons.

\#These values represent the average results of fruit weight loss percentage in 2008 and 2009 seasons.

The periodical measured weight loss percentages in stored fruits of both mango cultivars during storage period were recorded in the same table. From this table, it was cleared that stored fruits from trees pre-harvest sprayed with either vitamin C solution " $\mathrm{T}_{1}$ " or vitamin $\mathrm{B}_{12}$ solution " $\mathrm{T}_{2}$ " recorded weight loss percentages insignificantly differed compared with the control stored fruits. The tabulated periodical average values ranged from 00.00 to $7.02 \%, 00.00$ to $7.13 \%$ and 00.00 to $6.87 \%$ for Hindi fruits under $T_{c}$, $\mathrm{T}_{1}$ and $\mathrm{T}_{2}$ treatments, respectively. The corresponding average percentages, respectively for "Zibda" stored fruits in the same periodicals ranged from 00.00 to $6.37 \%, 00.00$ to $6.77 \%$ and 00.00 to $7.23 \%$. According to the tabulated results as explained above, it was noticed that the effect of antioxidant treatments on weight loss percentage of stored fruits of the two tested mango cultivars compared to the control treatment was insignificant in the two tested seasons.

$\mathrm{A}_{3}$. Chilling injury incidence $(\mathrm{Cl})$

The concerned results in Table (3) and illustrated in Figures (1\&2) clearly indicated a positive effect to the cultivar and treatment on chilling injury $(\mathrm{Cl})$ index. The tabulated index values for "Hindi" and "Zibda" stored fruits did not appear chilling injury symptoms till the $10^{\text {th }}$ day measurement $(00.00)$, afterward these index values pointed to light "Cl" symptoms at the fourth and fifth periodical measurements $\left(15^{\text {th }}\right.$ and $\left.20^{\text {th }}\right)$ with insignificant differences between the two tested antioxidant treatments. 
Samaan, L. G. et al.

Table (3): Effect of pre-harvest spray of mango trees cultivars Hindi and Zibda with 2 various antioxidant solutions on changes in fruits chilling injury index at harvest time (0) and 5-dayintervals during cold storage period at $5 \pm 1^{\circ} \mathrm{C}$ for 30 days.

\begin{tabular}{|c|c|c|c|c|c|c|c|c|c|}
\hline \multirow{2}{*}{\multicolumn{2}{|c|}{ Cultivar }} & \multirow{2}{*}{$\begin{array}{c}\text { Sym- } \\
\text { bol }\end{array}$} & \multicolumn{7}{|c|}{ Chilling injury index of fruits during storage in days } \\
\hline & & & 0 & 5 & 10 & 15 & 20 & 25 & 30 \\
\hline \multicolumn{2}{|r|}{ Hindi } & & 00.00 & 00.00 & 00.00 & $1.18^{\#}$ & 1.33 & 2.19 & 3.44 \\
\hline \multicolumn{2}{|r|}{ Zibda } & & 00.00 & 00.00 & 00.00 & 1.00 & 1.01 & 1.03 & 1.04 \\
\hline \multicolumn{2}{|c|}{$\mathrm{F}$ test } & & -- & -- & --- & N.S. & * & ** & ** \\
\hline \multicolumn{2}{|c|}{ Treatments } & & & & & & & & \\
\hline \multicolumn{2}{|c|}{ Water (control) } & $T_{c}$ & 00.00 & 00.00 & 00.00 & $1.19^{\#}$ & 1.35 & 1.76 & 2.22 \\
\hline \multirow{2}{*}{\multicolumn{2}{|c|}{$\begin{array}{c}\text { VitC } 1.0 \mathrm{gL}^{-1} \\
\text { Vit } 1.0 \mathrm{mgL}^{-1}\end{array}$}} & $T_{1}$ & 00.00 & 00.00 & 00.00 & 1.06 & 1.10 & 1.36 & 2.18 \\
\hline \multirow{2}{*}{\multicolumn{2}{|c|}{$\mathrm{Vit}_{\mathrm{B} 12} 1.0 \mathrm{mgL}^{-1}$}} & $T_{2}$ & 00.00 & 00.00 & 00.00 & 1.02 & 1.07 & 1.71 & 2.33 \\
\hline & & & -- & -- & -- & 0.23 & 0.11 & 0.14 & 0.15 \\
\hline Cultivar & Treatments & & & & & & & & \\
\hline \multirow{3}{*}{ Hindi } & Water (control) & $T_{c}$ & 00.00 & 00.00 & 00.00 & $1.38^{\#}$ & 1.69 & 2.50 & 3.40 \\
\hline & VitC $1.0 \mathrm{gL}^{-1}$ & $T_{1}$ & 00.00 & 00.00 & 00.00 & 1.11 & 1.19 & 1.71 & 3.36 \\
\hline & $\operatorname{Vit}_{\mathrm{B} 12} 1.0 \mathrm{mgL}^{-1}$ & $\mathrm{~T}_{2}$ & 00.00 & 00.00 & 00.00 & 1.05 & 1.11 & 2.36 & 3.57 \\
\hline \multirow{4}{*}{ Zibda } & Water (control) & $T_{c}$ & 00.00 & 00.00 & 00.00 & 1.00 & 1.00 & 1.02 & 1.04 \\
\hline & VitC $1.0 \mathrm{gL}^{-1}$ & $\mathrm{~T}_{1}$ & 00.00 & 00.00 & 00.00 & 1.00 & 1.00 & 1.00 & 1.00 \\
\hline & $\mathrm{Vit}_{\mathrm{B} 12} 1.0 \mathrm{mgL}^{-1}$ & $\mathrm{~T}_{2}$ & 00.00 & 00.00 & 00.00 & 1.00 & 1.02 & 1.07 & 1.09 \\
\hline & L.S.D 5\% & & & -- & & 0.26 & 0.13 & 0.14 & 0.13 \\
\hline
\end{tabular}

\#These values represent the average results of 2008 and 2009 seasons.

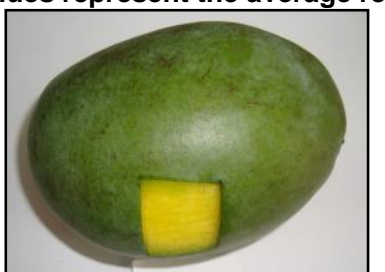

Tc

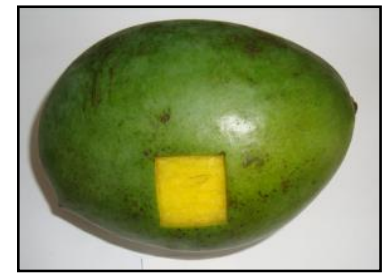

$\mathbf{T}_{1}$

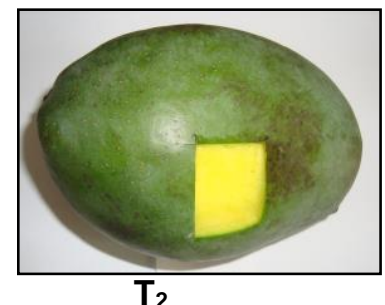

(Zibda)

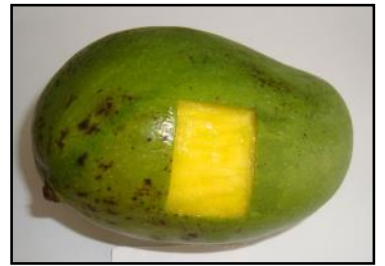

Tc

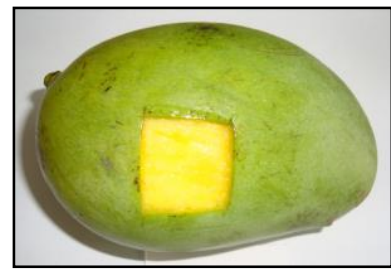

$\mathbf{T}_{1}$

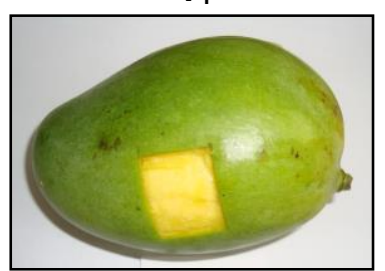

$\mathrm{T}_{2}$

(Hindi)

Figure (1): Photograph showing the effect of antioxidant treatments on chilling injury incidence on Hindi and Zibda fruits at $15^{\text {th }}$ day of cold storage period. 


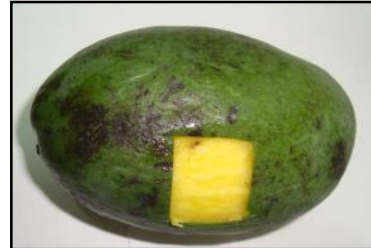

Tc
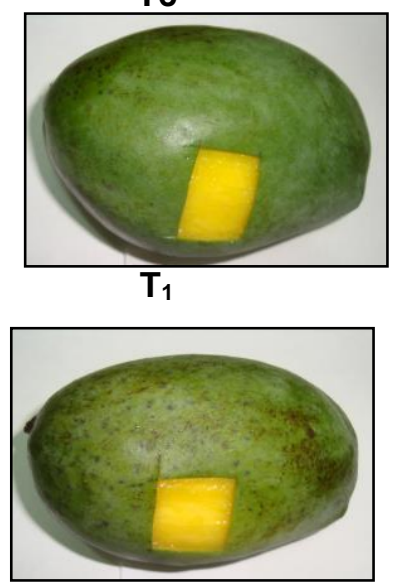

$T_{2}$

(Zibda)

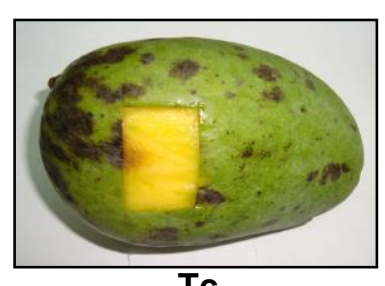

Tc

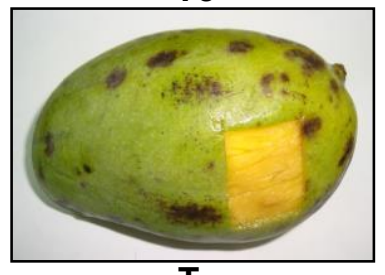

$\mathbf{T}_{1}$

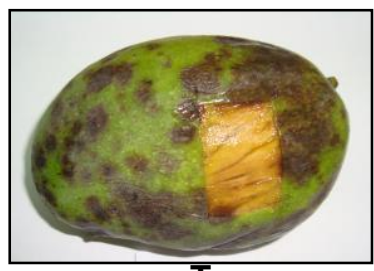

$\mathrm{T}_{2}$

Figure (2): Photograph showing the effect of antioxidant treatments on chilling injury incidence on Hindi and Zibda fruits at $30^{\text {th }}$ day of cold storage period.

Results in the same table showed that "Cl" index values of cold stored "Hindi" fruits significantly differed due to the two antioxidant treatments (1.71 and 2.36 for " $\mathrm{T}_{1}$ " and " $\mathrm{T}_{2}$ ", respectively) and between each of them and that of the control treatment (2.50) starting from day 25 till the end of storage period. During these later storage periods, fruits from trees of vitamin $\mathrm{B}_{12}$ treatment measured " $\mathrm{Cl}$ " index values significantly higher than those from trees treated with vitamin C. The significant increase of "Cl" incidence in that respect was resulted in stored fruits from the control trees. As for "Zibda" stored fruits, they had "Cl" symptoms free till day 15 and then the same fruits were mildly continued till the end of storage period with insignificant differences among the three tested treatments.

Accordingly, it could be reported that antioxidant treatments in case of "Hindi" stored fruits succeeded in extending shelf life of cold stored fruits, without "Cl" symptoms till the first 15 storage day and relatively minimize the incidence of "Cl" symptoms till 20 day. The super treatment in that respect was to pre-harvest vitamin C treatment " $T_{1}$ ". As for stored "Zibda" fruits all the tested treatments starting from $15^{\text {th }}$ day measurement caused mild "Cl" symptoms with insignificant differences till the end of storage period. It means that antioxidant treatments could be extend shelf life of stored cold fruits till 30 day storage period with mild of "Cl" symptoms starting from day 15 till the end of storage period. 
These results recorded an additional support to the significant effect of the cultivar genotype tested. Moreover, they are in complete agreement with those of Mohamed and Brecht (2002) who worked on mangoes of the cultivars "Keitt" and "Tommy" and observed that such fruits may be stored for two weeks at $5^{\circ} \mathrm{C}$ without chilling injury development. Tasneem (2004) evaluated the effect of different treatments included appropriate concentration of growth regulator methyl jasmonate or antioxidant diphenyl amine on mango fruits prior to storage at low temperature. He found that these treatments can reduce incidence of "Cl" symptoms and extend the shelf life of stored fruits. Best results were obtained with the combination of methyl jasmonate at 1 and $7^{\circ} \mathrm{C}$ and of antioxidant at 4 and $7^{\circ} \mathrm{C}$. More recent, Suwapanich and Haewsungcharoen (2007) reported that mango fruits cultivar "Nam Dok Mai Si Thong" harvested at fully mature green stage showed that peel pitting after 7-9 days storage at $5^{\circ} \mathrm{C}$.

In the same line, Zhao et al., (2009) working on mango fruits at different ripening stages and post-harvest stored at $2^{\circ} \mathrm{C}$ for 12 day. The results of "Cl" index indicated stronger resistance of pre-yellow and yellow fruits to "Cl" compared with green ones. They attributed that to the higher antioxidant capacity involved in the tolerance to chilling temperature. The "Cl" may be strongly alleviated in the fruit when skin color is beginning to change from green to yellow. Arafat (2009) came to a similar result with mango fruits, he attributed the positive effect of vitamin $\mathrm{C}$ application to inhibiting the form development of internal browning and maintaining to constant of the total phenols in mango fruits during cold storage.

Our results also in harmony with Cao et al., (2009) who worked on loquat fruits to study the correlate between methyl jasmonate effect on the incidence of "Cl" symptoms and changes in the antioxidant system as judged by activity of certain enzymes. Finally, they suggested that the reduction in "Cl" incidence on fruit post-harvest treated with methyl jasmonate solution may be due to enhancing in antioxidant enzymes activity.

According to the obtained results of the above three physical characteristics measured at harvest time and during storage period on stored fruits of mango cultivars "Hindi" and "Zibda", it was cleared that changes in fruit firmness and chilling injury incidence were greatly differed due to the cultivar, treatment or both. Moreover, this part of the study also revealed a gradual decrease in fruit firmness and an increase in weight loss\% during cold storage as the storage period advanced. A similar trend as indicated above was also noticed with "Cl" incidence in case of "Hindi" stored fruits. These behaviors of the measured physical characteristics during storage period could be attributed to the decrease in concentration of antioxidants in fruit as the fruit advanced in ripening and the free radical scavenging activity may depend on the concentration and composition of antioxidants. This explanation was previously reported by Kondo et al., (2002) who worked with three apple cultivars to associate between antioxidants activity and fruit development. 


\section{B. Effect of pre-harvest antioxidant treatments on six fruit chemical characteristics determined at harvest time and during cold storage period}

This part of the study is dealing with six fruit chemical characteristics that participate in determining the acceptable quality to the consumers. They have generally focused on the treated fruit juice and peels at harvest time and their changes at 5 -day-periodicals during cold storage period for 30 day.

\section{$B_{1}$. Changes in fruit juice vitamin C content (Ascorbic acid)}

Results recorded in Table (4) showed that Vitamin C behavior in fruit juice differed due to the tested cultivar and treatment. At harvest time, fruits of the cultivar "Hindi" from trees pre-harvest sprayed with Vitamin C solution at $1.0 \mathrm{gL}^{-1}$ " $\mathrm{T}_{1}$ " significantly recorded the highest content with the average value of $38.78 \mathrm{mg} / 100 \mathrm{ml}$ juice. The next average value was in fruit juice of control treatment " $\mathrm{T}_{c}$ " $(31.09 \mathrm{mg} / 100 \mathrm{ml})$, whereas the least content resulted in fruits juice of trees pre-harvest sprayed with Vitamin $B_{12}$ solution at $1.0 \mathrm{mgL}^{-1}$ " $\mathrm{T}_{2}$ " with an average value of $27.56 \mathrm{mg} / 100 \mathrm{ml}$ juice. As for the cultivar "Zibda", the superiority was to Vitamin $B_{12}$ treatment. It produced fruits contained the highest average value of Vitamin $C(49.12 \mathrm{mg} / 100 \mathrm{ml}$ juice) followed by fruits of Vitamin C treatment $(46.64 \mathrm{mg} / 100 \mathrm{ml}$ juice), whereas the fewest value resulted in the control fruits $(30.21 \mathrm{mg} / 100 \mathrm{ml}$ juice).

The periodical determinations of Vitamin $C$ content in stored fruits during cold storage period as presented in the same table indicated an obvious increase in fruit Vitamin $\mathrm{C}$ of both cultivars reached the peak level at $10^{\text {th }}$ day determination by the super treatment " $\mathrm{T}_{1}$ " with the average value of $48.14 \mathrm{mg} / 100 \mathrm{ml}$ juice for "Hindi" stored fruits along with $76.94 \mathrm{mg} / 100 \mathrm{ml}$ juice for "Zibda" ones. These higher values relatively can be extended till day 15 with the average values of 46.73 and $70.58 \mathrm{mg} / 100 \mathrm{ml}$ juice for both cultivars, respectively. After such peak days, vitamin $\mathrm{C}$ content in juice of both cultivars stored fruits from trees under the three tested treatments was gradually decreased till the end of storage period ( $30^{\text {th }}$ day determination). It reached in "Hindi" fruits at the $30^{\text {th }}$ storage day the average values of 39.66 for " $\mathrm{T}_{1}$ ", 27.56 for " $\mathrm{T}_{2}$ " and $37.54 \mathrm{mg} / 100 \mathrm{ml}$ juice for " $\mathrm{T}_{\mathrm{c}}$ ". As for "Zibda", the corresponding average values, respectively were $62.81,61.75$ and $55.39 \mathrm{mg} / 100 \mathrm{ml}$ juice.

Concerning the above results, it could be cleared that the tested antioxidant treatments on vitamin C content in "Zibda" fruit juice had an increasing effect much better than on "Hindi" fruit juice either at harvest time or during storage period. This was confirmed by the significant higher values tabulated for fruit juice of the former cultivar if compared to those of the later one at harvest time and all over storage period. It is a point of interest also to refer herein that the effect of pre-harvest spray "Zibda" trees with Vitamin $\mathrm{B}_{12}$ solution at $1.0 \mathrm{mgL}^{-1}$ " $\mathrm{T}_{2}$ " produced fruits contained vitamin $\mathrm{C}$ significantly higher than the same treatment on "Hindi" trees. Fruits of the former cultivar tabulated Vitamin $C$ average values starting from harvest time to the end of storage period ranged from 49.12 to $61.75 \mathrm{mg} / 100 \mathrm{ml}$ juice with an average peak value of $67.22 \mathrm{mg} / 100 \mathrm{ml}$ juice on the $20^{\text {th }}$ day. As for the later cultivar, fruits from trees under the same treatment determined vitamin $\mathrm{C}$ ranged from 27.56 to $27.56 \mathrm{mg} / 100 \mathrm{ml}$ juice with an average peak value of 37.63 $\mathrm{mg} / 100 \mathrm{ml}$ juice on the $10^{\text {th }}$ day determination. 
Table (4): Effect of pre-harvest spray of mango trees cultivars Hindi and Zibda with 2 various antioxidant solutions on changes in vitamin $C$ content at harvest time (0) and 5-day-intervals during cold storage period at $5 \pm 1^{\circ} \mathrm{C}$ for 30 days.

\begin{tabular}{|c|c|c|c|c|c|c|c|c|c|}
\hline \multirow{2}{*}{\multicolumn{2}{|c|}{ Cultivar }} & \multirow{2}{*}{$\begin{array}{l}\text { Sym } \\
\text {-bol }\end{array}$} & \multicolumn{7}{|c|}{$\begin{array}{l}\text { Vitamin C content in fruit juice during storage in } \\
\text { days }\end{array}$} \\
\hline & & & 0 & 5 & 10 & 15 & 20 & 25 & 30 \\
\hline \multicolumn{2}{|r|}{ Hindi } & & $32.48^{\#}$ & 37.34 & 43.02 & 40.08 & 38.37 & 36.90 & 34.92 \\
\hline \multicolumn{2}{|r|}{ Zibda } & & 41.99 & 52.35 & 62.57 & 63.53 & 64.19 & 62.19 & 59.98 \\
\hline \multicolumn{2}{|r|}{ F test } & & $* *$ & $\star *$ & $* *$ & $\star *$ & $* *$ & $\star *$ & $\star *$ \\
\hline \multicolumn{10}{|c|}{ Treatments } \\
\hline \multicolumn{2}{|c|}{ Water (control) } & $T_{c}$ & $30.66^{\#}$ & 40.41 & 51.06 & 49.56 & 49.03 & 47.08 & 46.47 \\
\hline \multicolumn{2}{|c|}{ VitC $1.0 \mathrm{gL}^{-1}$} & $\mathrm{~T}_{1}$ & 42.71 & 52.87 & 62.54 & 58.66 & 55.61 & 54.33 & 51.24 \\
\hline \multicolumn{2}{|c|}{$\operatorname{Vit}_{\mathrm{B} 12} 1.0 \mathrm{mgL}^{-1}$} & $\mathrm{~T}_{2}$ & 38.34 & 41.25 & 44.79 & 47.20 & 49.20 & 47.22 & 44.65 \\
\hline \multicolumn{2}{|c|}{ L.S.D $5 \%$} & & 0.60 & 0.47 & 1.00 & 0.76 & 1.45 & 0.64 & 1.28 \\
\hline Cultivar & Treatments & & & & & & & & \\
\hline \multirow{3}{*}{ Hindi } & Water (control) & $\mathrm{T}_{\mathrm{c}}$ & $31.09^{\#}$ & 35.86 & 43.28 & 40.55 & 40.28 & 37.63 & 37.54 \\
\hline & VitC $1.0 \mathrm{gL}^{-1}$ & $\mathrm{~T}_{1}$ & 38.78 & 43.29 & 48.14 & 46.73 & 43.64 & 43.38 & 39.66 \\
\hline & $\mathrm{Vit}_{\mathrm{B} 12} 1.0 \mathrm{mgL}^{-1}$ & $\mathrm{~T}_{2}$ & 27.56 & 32.86 & 37.63 & 32.95 & 31.18 & 29.68 & 27.56 \\
\hline \multirow{3}{*}{ Zibda } & Water (control) & $\mathrm{T}_{\mathrm{c}}$ & 30.21 & 44.96 & 58.83 & 58.57 & 57.77 & 56.54 & 55.39 \\
\hline & VitC $1.0 \mathrm{gL}^{-1}$ & $\mathrm{~T}_{1}$ & 46.64 & 62.45 & 76.94 & 70.58 & 67.58 & 65.28 & 62.81 \\
\hline & $V_{\text {it }} 121.0 \mathrm{mgL}^{-1}$ & $T_{2}$ & 49.12 & 49.65 & 51.94 & 61.45 & 67.22 & 64.75 & 61.75 \\
\hline \multicolumn{2}{|c|}{ L.S.D 5\% } & & 0.61 & 0.50 & 1.12 & 0.82 & 0.75 & 1.61 & 0.61 \\
\hline
\end{tabular}

\# These values represent the average results of 2008 and 2009 seasons.

The increase of vitamin $\mathrm{C}$ content in juice of fruits from trees under antioxidant treatments previously was explained in the study of Lim et al., (2006) who reported that fruit ripening continues after harvest and during storage. This process leads to significant changes in the contents of the antioxidants, where observed an increase in ascorbic acid during storage of ripe and unripe guava fruits at $4^{\circ} \mathrm{C}$ and attributed that to after harvest ascorbic acid still synthesized in the living fruit tissues.

\section{$B_{2}$. Changes in fruit juice acidity percentage}

The listed results in Table (5) indicated that acidity percentage in fruit juice of both mango cultivars under study significantly was affected by either cultivar or treatment tested. At harvest time, fruits resulted on trees preharvest sprayed with vitamin $B_{12}$ solution at $1.0 \mathrm{mgL}^{-1}$ " $\mathrm{T}_{2}$ " gave the lowest average acidity \% in juice compared with those from trees under the two other treatments. This was clear in "Hindi" and "Zibda" fruit juice in the two seasons of study. It is important to record herein that "Zibda" untreated trees produced at harvest time fruits contained acidity \% (2.77\%) significantly lower than those from untreated "Hindi" trees (3.78\%). This confirmed the statement that the cultivar genotype has a positive effect in that respect.

Concerning changes during storage period, the periodical determinations revealed a decline in juice acidity\% throughout storage period. Such decrease was sharp in fruits from trees pre-harvest sprayed with each of the two antioxidants solution ( $T_{1}$ and $\left.T_{2}\right)$ or untreated " $T_{c}$ ". The highest decrease was occurred at the end of storage period. It was also noticed that the tested treatments on "Hindi" stored fruits had a significant 
decrease than that on "Zibda" stored ones in the same seasons. Consequently, it could be reported that antioxidant treatments had a decreasing effect on juice acidity \% of stored fruits. Such decrease was the highest in juice of fruits from trees pre-harvest sprayed with vitamin $B_{12}$ solution at $1.0 \mathrm{mgL}^{-1}$ " $\mathrm{T}_{2}$ ", since they averaged at harvest time acidity $\%$ of 2.09 and $2.06 \%$ for "Hindi" and "Zibda", respectively as well as at the end of storage period they averaged 0.41 and $0.89 \%$. The next effect in that respect was to " $\mathrm{T}_{1}$ " treatment with the average values at harvest time 3.30 and $2.67 \%$ along with 0.57 and $0.91 \%$ at the end of storage period for "Hindi" and "Zibda" cultivars, respectively. The lowest decrease was resulted in fruit juice of the control trees.

Table (5): Effect of pre-harvest spray of mango trees cultivars Hindi and Zibda with 2 various antioxidant solutions on changes in acidity percentage at harvest time (0) and 5-day-intervals during cold storage period at $5 \pm 1^{\circ} \mathrm{C}$ for 30 days.

\begin{tabular}{|c|c|c|c|c|c|c|c|c|c|}
\hline \multirow{2}{*}{\multicolumn{2}{|c|}{ Cultivar }} & \multirow{2}{*}{$\begin{array}{c}\text { Sym- } \\
\text { bol }\end{array}$} & \multicolumn{7}{|c|}{$\begin{array}{l}\text { Acidity percentage in fruit juice during storage } \\
\text { in days }\end{array}$} \\
\hline & & & 0 & 5 & 10 & 15 & 20 & 25 & 30 \\
\hline \multicolumn{2}{|r|}{ Hindi } & & $3.06^{\#}$ & 2.25 & 1.34 & 1.06 & 0.78 & 0.64 & 0.50 \\
\hline \multicolumn{2}{|r|}{ Zibda } & & 2.50 & 2.21 & 2.01 & 1.79 & 1.28 & 1.15 & 0.97 \\
\hline \multicolumn{2}{|r|}{$\mathrm{F}$ test } & & $\star \star$ & * & $\star \star$ & $\star *$ & $\star \star$ & $\star \star$ & $\star *$ \\
\hline \multicolumn{2}{|c|}{ Treatments } & & & & & & & & \\
\hline \multicolumn{2}{|c|}{ Water (control) } & $T_{c}$ & $3.27^{\#}$ & 2.61 & 1.92 & 1.47 & 0.91 & 0.85 & 0.83 \\
\hline \multicolumn{2}{|c|}{ VitC $1.0 \mathrm{gL}^{-1}$} & $\mathrm{~T}_{1}$ & 2.99 & 2.33 & 1.62 & 1.49 & 1.07 & 0.91 & 0.74 \\
\hline \multicolumn{2}{|c|}{ VitB12 $1.0 \mathrm{mgL}^{-1}$} & $\mathrm{~T}_{2}$ & 2.08 & 1.75 & 1.48 & 1.32 & 1.10 & 0.93 & 0.65 \\
\hline \multicolumn{2}{|c|}{ L.S.D $5 \%$} & & 0.09 & 0.05 & 0.08 & 0.07 & 0.11 & 0.07 & 0.05 \\
\hline Cultivar & Treatments & & & & & & & & \\
\hline \multirow{3}{*}{ Hindi } & Water (control) & $T_{c}$ & $3.78^{\#}$ & 2.50 & 1.22 & 0.94 & 0.68 & 0.59 & 0.53 \\
\hline & VitC $1.0 \mathrm{gL}^{-1}$ & $\mathrm{~T}_{1}$ & 3.30 & 2.31 & 1.23 & 0.98 & 0.75 & 0.67 & 0.57 \\
\hline & Vit$_{\mathrm{B} 12} 1.0 \mathrm{mgL}^{-1}$ & $\mathrm{~T}_{2}$ & 2.09 & 1.94 & 1.57 & 1.27 & 0.91 & 0.67 & 0.41 \\
\hline \multirow{3}{*}{ Zibda } & Water (control) & $\mathrm{T}_{\mathrm{c}}$ & 2.77 & 2.72 & 2.62 & 2.00 & 1.14 & 1.11 & 1.12 \\
\hline & VitC $1.0 \mathrm{gL}^{-1}$ & $\mathrm{~T}_{1}$ & 2.67 & 2.36 & 2.01 & 2.00 & 1.40 & 1.16 & 0.91 \\
\hline & Vit $_{\mathrm{B} 12} 1.0 \mathrm{mgL}^{-1}$ & $\mathrm{~T}_{2}$ & 2.06 & 1.55 & 1.39 & 1.37 & 1.28 & 1.18 & 0.89 \\
\hline \multicolumn{2}{|r|}{ L.S.D 5\% } & & 0.07 & 0.06 & 0.07 & 0.07 & 0.10 & 0.07 & 0.05 \\
\hline
\end{tabular}

\# These values represent the average results of 2008 and 2009 seasons.

The decreasing effect of antioxidant treatments on fruit juice acidity \% might be due to the activation of certain enzymes concerning with degradation of citric acid during storage by antioxidants tested. Such explanation agree with that reported by Rathore et al., (2007)on mango var.Dosehari who attributed the decrease of titratable acidity during storage period to degradation of citric acid as a result of increased activity of citric acid glyoxylase enzyme during ripening. This may be lead to their conversion into sugars and their further utilization in metabolic process in the fruit $B_{3}$. Changes in total soluble solids percentage (TSS \%) of fruit juice

The concerned results in Table (6) showed that total soluble solids\% in fruit juice of "Hindi" and "Zibda" differed due to either the cultivar or treatment tested. At harvest time, these results proved that among the tested 
treatments the most effective one to produce "Zibda" fruits contained higher TSS\% in juice $(9.79 \%)$ was that of pre-harvest sprayed trees with vitamin $\mathrm{B}_{12}$ solution. Otherwise, the control " $\mathrm{T}_{c}$ " was the super treatment with "Hindi" trees $(9.73 \%)$ followed by either " $\mathrm{T}_{1}$ " $(9.06 \%)$ or " $\mathrm{T}_{2}$ " $(8.51 \%)$. The difference between these two antioxidant treatments was insignificant.

Table (6): Effect of pre-harvest spray of mango trees cultivars Hindi and Zibda with 2 various antioxidant solutions on changes in TSS percentage at harvest time $(0)$ and 5-day-intervals during cold storage period at $5 \pm 1^{\circ} \mathrm{C}$ for 30 days.

\begin{tabular}{|c|c|c|c|c|c|c|c|c|c|}
\hline \multicolumn{2}{|c|}{ Cultivar } & \multirow[t]{2}{*}{$\begin{array}{c}\text { Sym- } \\
\text { bol }\end{array}$} & \multicolumn{7}{|c|}{$\begin{array}{l}\text { TSS percentage in fruit juice during storage in } \\
\text { days }\end{array}$} \\
\hline & & 0 & 5 & 10 & 15 & 20 & 25 & 30 \\
\hline \multicolumn{2}{|r|}{ Hindi } & & $9.10^{\#}$ & 10.48 & 12.50 & 12.68 & 13.20 & 14.04 & 15.06 \\
\hline \multicolumn{2}{|r|}{ Zibda } & & 7.66 & 8.62 & 10.11 & 11.04 & 11.93 & 12.66 & 13.34 \\
\hline \multicolumn{2}{|r|}{$\mathrm{F}$ test } & & ${ }^{*}$ & & ** & ** & ** & *** & ** \\
\hline \multicolumn{10}{|c|}{ Treatments } \\
\hline \multicolumn{2}{|c|}{ Water (control) } & $T_{c}$ & $8.10^{\#}$ & 9.87 & 12.53 & 12.85 & 13.45 & 13.33 & 13.27 \\
\hline \multicolumn{2}{|c|}{ VitC $1.0 \mathrm{gL}^{-1}$} & $T_{1}$ & 7.89 & 8.58 & 10.09 & 11.18 & 12.28 & 14. & 15.70 \\
\hline \multirow{2}{*}{\multicolumn{2}{|c|}{$\frac{\text { VitB12 } 1.0 \mathrm{mgL}^{-1}}{\text { L.S.D } 5 \%}$}} & $\mathrm{~T}_{2}$ & 9.15 & 10.21 & 11. & 11.56 & 11.96 & 12. & 13.63 \\
\hline & & & 0.33 & 0.86 & & 0.15 & & & 0.09 \\
\hline \multicolumn{10}{|c|}{\begin{tabular}{|l|l|} 
ar & Treatments \\
\end{tabular}} \\
\hline \multirow{3}{*}{ Hindi } & Water (control) & $T_{c}$ & $9.73^{\#}$ & 11.58 & 14.07 & 14.13 & 14.97 & 14.38 & 13.92 \\
\hline & & $T_{1}$ & 9.06 & 10.29 & 12.85 & 13.18 & 13.50 & & 17.33 \\
\hline & $\operatorname{Vit}_{\mathrm{B} 121.0}$ & $\mathrm{~T}_{2}$ & 8.51 & 9.57 & 10.58 & 10.73 & 11.13 & 12.32 & 13.92 \\
\hline \multirow{3}{*}{ Zibda } & Water (cor & $T_{c}$ & 6.47 & 8.15 & 10.98 & 11.57 & 11.93 & 12.28 & 12.62 \\
\hline & & $T_{1}$ & & & 7.33 & 9.17 & 11.07 & 12.62 & 14.07 \\
\hline & VitB121.0mgL ${ }^{-1}$ & $T_{2}$ & 9.79 & 10.85 & 12.02 & 12.38 & 12.78 & 13.08 & 13.33 \\
\hline \multicolumn{2}{|c|}{ L.S.D 5\% } & & 0.75 & 0.68 & 0.17 & 0.15 & 0.09 & 0.08 & 0.14 \\
\hline
\end{tabular}

\# These values represent the average results of 2008 and 2009 seasons.

As for changes in juice TSS\% during cold storage period, the periodical determination of both cultivars under almost all treatments as presented in the same table clearly showed a gradual increase in this juice characteristic as the storage period advanced. The rate of increase significantly was differed according to the treatment tested. The highest increase was in fruit juice of the two tested cultivars from trees under vitamin $C$ treatment " $T_{1}$ ". Starting from harvest time to the end of storage period, "Hindi" fruit juice valued an average ranged from 9.06 to $17.33 \%$ and those for "Zibda" fruit juice were from 6.73 to $14.07 \%$. The next increasing effect was to vitamin $B_{12}$ treatment " $T_{2}$ "with average ranges from 8.51 to $13.92 \%$ for "Hindi" fruits and from 9.79 to $13.33 \%$ for "Zibda" ones. The least increase was tabulated for fruits of the control trees " $\mathrm{T}_{\mathrm{c}}$ " with the average ranges from 9.73 to $13.92 \%$ for "Hindi" fruits as well as from 6.47 to $12.62 \%$ for "Zibda" ones.

Referring to the above results, it could be concluded that among the tested antioxidant treatments, relatively, the better one to harvest "Hindi" fruits contained higher TSS\% in juice was " $\mathrm{T}_{1}$ " treatment $(9.06 \%)$ followed by 
"T2" treatment $(8.51 \%)$ with insignificant difference between them. Moreover this super effect of " $\mathrm{T}_{1}$ " treatment on TSS\% in juice of "Hindi" fruits significantly was higher than its effect on TSS\% in fruit juice of "Zibda" $(6.73 \%)$. This was true either at harvest time or throughout cold storage period. As for "Zibda" fruits, the superiority among the tested treatments was to " $\mathrm{T}_{2}$ " treatment, since it produced fruits significantly of the highest TSS\% in juice $(9.79 \%)$ followed by "T $\mathrm{T}_{1}$ " treatment $(6.73 \%)$, whereas the fewest TSS\% was in juice of the control fruits $(6.47 \%)$. This behavior was at both harvest time and during cold storage period. The increasing effect of antioxidant treatments on TSS\% in juice of the stored fruits of both cultivars along with the different effective rates might be due to the activating effect of antioxidants under study on hydrolytic enzymes during storage period that leads to breakdown of complex carbohydrates into simple sugars. This attribution is in complete agreement with Kays (1991) and Kittur et al., (2001) who worked on mango and other climacteric fruits. They directly correlated the increase and decrease in TSS\% with hydrolytic changes in starch and the conversion of starch to sugar being an important index of ripening process in fruit.

\section{$B_{4}$. Changes in fruit juice TSS/acid ratio}

Before reviewing and discussing the results obtained in the current characteristic, it might be important to report that fruit flesh taste is highly dependent on the balance between organic acids and soluble sugars which are predominantly represented in mango by citric and malic acids, along with sucrose, fructose and glucose (Medlicott and Thompson, 1985). The calculated TSS/acid ratios as presented in Table (7) revealed that these ratios in fruit juice of the two mango cultivars were greatly affected by the cultivar and treatment tested.

At harvest time among the tested treatments the most effective treatment was that of pre-harvest sprayed trees with vitamin $B_{12}$ solution which significantly produced fruits having the highest TSS/acid ratios with an average of 4.08 and 4.78 for "Hindi" and "Zibda" cultivars, respectively. The next in that respect was resulted in juice of fruits from trees under vitamin $\mathrm{C}$ treatment " $\mathrm{T}_{1}$ " with respectively the average ratios 2.76 and 2.53 . The fewest ratios were resulted in fruit juice of the control trees " $\mathrm{T}_{c}$ " with the average ratios 2.58 and 2.35 for "Hindi" and "Zibda" cultivars, respectively.

Concerning changes in TSS/acid ratios during cold storage period, the results in the same table indicate that these ratios in mangoes of both cultivars were gradually increased as storage period advanced. Antioxidant treatments had the upper hand to cause a significant effect compared with the control one. The superiority in that respect was to vitamin $B_{12}$ treatment " $\mathrm{T}_{2}$ " followed by vitamin $\mathrm{C}$ one on both tested mango cultivars. The periodical calculated ratios during storage period for such super treatment were ranged from 4.08 to 35.48 in "Hindi" stored fruits and from 4.78 to 15.14 in "Zibda" stored fruits. The corresponding average ranges in fruit juice of vitamin $\mathrm{C}$ treatment were from 2.76 to 31.09 and from 2.53 to 15.53 for "Hindi" and "Zibda", respectively. As for the control fruit juice of both cultivars, respectively were from 2.58 to 26.78 and from 2.35 to 11.33 . The concerned results in Table (7) also revealed that TSS/acid ratios in "Hindi" stored fruit 
juice from trees under the tested treatments were significantly higher than those in "Zibda" stored fruit juice. Such increase was true all over the periodical calculations.

Table (7): Effect of pre-harvest spray of mango trees cultivars Hindi and Zibda with 2 various antioxidant solutions on changes in TSS/acid ratio at harvest time $(0)$ and 5-day-intervals during cold storage period at $5 \pm 1^{\circ} \mathrm{C}$ for 30 days.

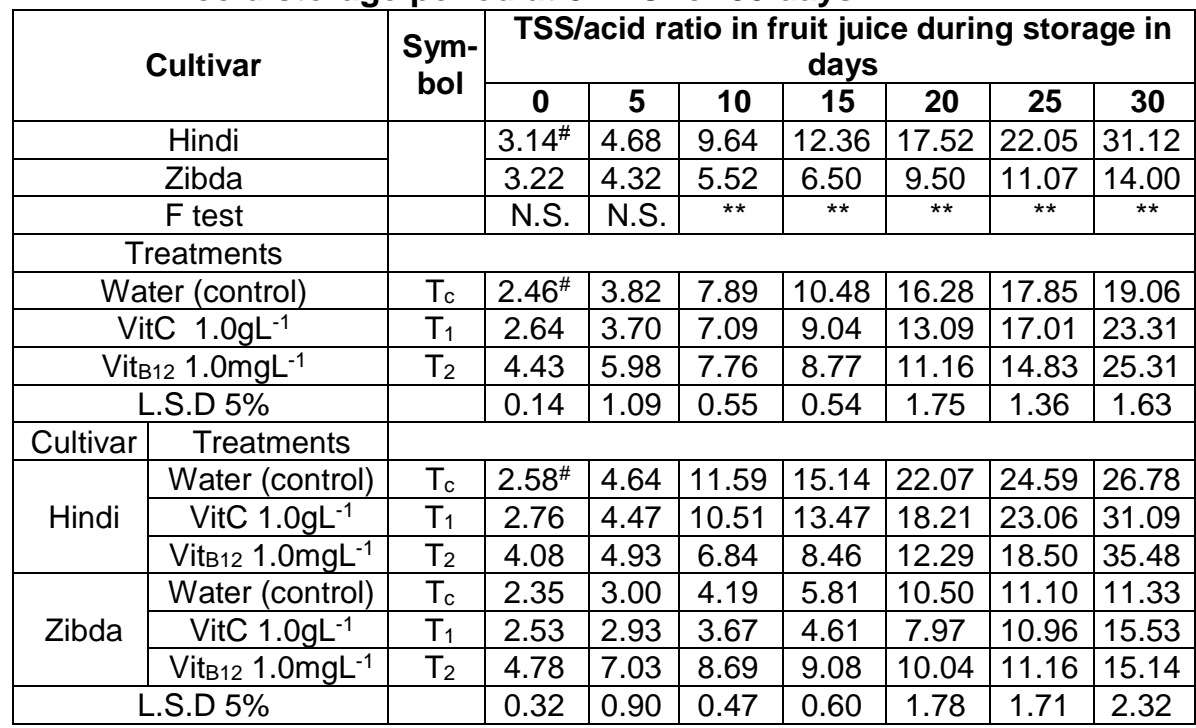

\#These values represent the average results of 2008 and 2009 seasons.

\section{$B_{5}$. Changes in fruit peel pigment contents of fruit juice}

This part of study concerned with the obtained results of fresh peel $\beta$ carotene and total chlorophyll contents in mangoes of the two tested cultivars at harvest time and during cold storage period. The determined values of both pigments were recorded in Tables (8\&9). From these tables, it was noticed that these peel pigments were greatly affected by either the cultivar or treatment tested. At harvest time, the pre-harvest sprayed trees of mango cultivars, "Hindi" and "Zibda" with Vitamin $\mathrm{B}_{12}$ at $1.0 \mathrm{mgL}^{-1}$ " $\mathrm{T}_{2}$ " produced fruits contained a higher $\beta$-carotene in fresh peels compared with Vitamin $C$ treatment " $T_{1}$ ". The tabulated average values for both cultivars, respectively under this super treatment were 59.18 and $75.10 \mu \mathrm{g} / \mathrm{g}$ fresh peels. The average values of "Hindi" and "Zibda" fruits from trees under " $\mathrm{T}_{1}$ " treatments were 37.46 and $45.70 \mu \mathrm{g} / \mathrm{g}$ fresh peels, respectively. The corresponding average values in fresh fruit peels from trees of " $\mathrm{T}_{\mathrm{c}}$ " treatment were 43.75 and $89.22 \mu \mathrm{g} / \mathrm{g}$ fresh peels. It is a point of interest to explain herein that "Zibda" fruits from the control trees " $\mathrm{T}_{c}$ " at harvest time determined an average value of $\beta$-carotene $(89.22 \mu \mathrm{g} / \mathrm{g}$ fresh peels) significantly higher than that in fruit peels from " $\mathrm{T}_{2}$ " treatment trees $(75.10 \mu \mathrm{g} / \mathrm{g}$ fresh peels). This trend was not observed in fresh peels of "Hindi" stored fruits. Consequently, it could be reported that pre-harvest sprayed "Zibda" trees with vitamin $B_{12}$ 
solution at $1.0 \mathrm{mgL}^{-1}$ had a negative effect on $\beta$-carotene content in fresh peels of the harvested fruits. Otherwise, this treatment caused a positive effect on the same pigment on fresh peels of "Hindi" harvested fruits. This conclusion once again confirmed the active role of cultivar genotype in that respect.

Table (8): Effect of pre-harvest spray of mango trees cultivars Hindi and Zibda with 2 various antioxidant solutions on changes in $\beta$.carotene content in fruit fresh peels at harvest time (0) and 5day-intervals during cold storage period at $5 \pm 1^{\circ} \mathrm{C}$ for 30 days.

\begin{tabular}{|c|c|c|c|c|c|c|c|c|c|}
\hline \multirow{2}{*}{\multicolumn{2}{|c|}{ Cultivar }} & \multirow{2}{*}{$\begin{array}{c}\text { Sym } \\
- \\
\text { bol }\end{array}$} & \multicolumn{7}{|c|}{$\begin{array}{c}\text { B.carotene content in fruit fresh peels during } \\
\text { storage in days }(\mu \mathrm{g} / \mathrm{g} \text { peels) }\end{array}$} \\
\hline & & & 0 & 5 & 10 & 15 & 20 & 25 & 30 \\
\hline \multicolumn{2}{|r|}{ Hindi } & & $46.79^{\#}$ & 54.45 & 61.22 & 85.72 & 99.46 & 109.85 & \begin{tabular}{|l|l|}
519.83 \\
\end{tabular} \\
\hline \multicolumn{2}{|r|}{ Zibda } & & 70.01 & 80.60 & 98.84 & 122.97 & 146.25 & 148.83 & \begin{tabular}{|l|l|}
150.26 \\
\end{tabular} \\
\hline \multicolumn{2}{|r|}{$F$ test } & & & & ** & ** & $* *$ & $* *$ & ${ }^{* *}$ \\
\hline \multicolumn{10}{|c|}{ Treatments } \\
\hline \multicolumn{2}{|c|}{ Water (control) } & $T_{c}$ & $66.48^{\#}$ & 75.92 & 95.96 & 107.32 & 111 & \begin{tabular}{|l|}
124.89 \\
\end{tabular} & 137.95 \\
\hline \multicolumn{2}{|c|}{ VitC $1.0 \mathrm{gL}^{-1}$} & & 41.58 & 47.65 & 55.09 & & & & 36.87 \\
\hline \multirow{2}{*}{\multicolumn{2}{|c|}{$\begin{array}{l}\text { VitB12 } 1.0 \mathrm{mgL}^{-1} \\
\text { L.S.D } 5 \%\end{array}$}} & $T_{2}$ & 67.14 & 79.00 & 89.04 & 105.66 & 126.91 & 128.96 & 130.32 \\
\hline & & & 1.37 & 0.95 & 1.53 & 0.75 & \begin{tabular}{|l|}
2.17 \\
\end{tabular} & 2.02 & 1.77 \\
\hline ultivar & Treatme & & & & & & & & \\
\hline \multirow{3}{*}{ Hindi } & & $T_{c}$ & $43.75^{\#}$ & 49.65 & 61.68 & 80.34 & 81.55 & 104.28 & 128.59 \\
\hline & VitC $1.0 \mathrm{gL}^{-1}$ & $T_{1}$ & 37.46 & 42.48 & 47.71 & 82.55 & 113.99 & 118.84 & 122.38 \\
\hline & VitB12 $1.0 \mathrm{mgL}$ & $\mathrm{T}_{2}$ & 59.18 & 71.22 & 74.27 & 94.27 & 102.86 & 106.44 & 108.51 \\
\hline \multirow{3}{*}{ Zibda } & Water & $T_{c}$ & 89.22 & 102.20 & 130.24 & 134.29 & 140.47 & 145.50 & 147.30 \\
\hline & VitC $1.0 \mathrm{gL}^{-1}$ & $\mathrm{~T}_{1}$ & 45.71 & 52.82 & 62.46 & 117.56 & 147.31 & 149.50 & 151.35 \\
\hline & $V^{2} t_{B 12} 1.0 \mathrm{~m}$ & $\mathrm{~T}_{2}$ & 75.10 & 86.77 & 103.81 & 117.04 & 150.97 & 151.48 & 152.12 \\
\hline \multicolumn{2}{|c|}{ L.S.D 5\% } & & 3.17 & 1.98 & 1.70 & 0.83 & 2.82 & 1.49 & 1.65 \\
\hline
\end{tabular}

\#These values represent the average results of 2008 and 2009 seasons.

As for changes during cold storage period, the concerned data in Table (8) showed an increase due to the tested treatments on $\beta$-Carotene content in fresh peel of "Hindi" and "Zibda" stored fruits during 30 day storage. The rate of increase differed among the tested treatments. In case of "Hindi" stored fruits of " $\mathrm{T}_{2}$ " treatment, the determined $\beta$-carotene values significantly were higher till day 15 if compared with those tabulated for either " $\mathrm{T}_{1}$ " or " $\mathrm{T}_{\mathrm{c}}$ " stored fruits. During the period from harvest time (0) to day 15 fruit fresh peels from " $\mathrm{T}_{2}$ " trees tabulated an average range from 59.18 to $94.27 \mu \mathrm{g} / \mathrm{g}$ fresh peels. The corresponding range in fruit fresh peels of " $\mathrm{T}_{1}$ " trees was from 37.46 to $82.55 \mu \mathrm{g} / \mathrm{g}$ fresh peels in the same seasons. As for fresh peels of fruits from " $\mathrm{T}_{c}$ " trees, they ranged from 43.75 to $80.34 \mu \mathrm{g} / \mathrm{g}$ fresh peels. Starting from the $20^{\text {th }}$ day determination till the end of storage period an opposite trend was detected, since the upper hand was to " $\mathrm{T}_{1}$ " treatment with $\beta$-carotene content during the later storage period (from 113.98 to $122.39 \mu \mathrm{g} / \mathrm{g}$ fresh peels) significantly were higher than those from " $\mathrm{T}_{2}$ " trees (from 102.86 to $108.51 \mu \mathrm{g} / \mathrm{g}$ fresh peels). 
As for "Zibda" stored fruits an almost similar trend was observed with the control stored fruits till the $15^{\text {th }}$ day determination. The stored fruits of " $\mathrm{T}_{\mathrm{c}}$ " treatment determined $\beta$-carotene content in fresh peels of a significant increase over stored ones of either " $\mathrm{T}_{1}$ " or " $\mathrm{T}_{2}$ " treatments during this storage period. Afterward, the superiority was to the two antioxidant treatments till the end of storage period with significant difference between each of them and " $T_{c}$ " treatment. At the former storage period (from 0 to $15^{\text {th }}$ day determination) $\beta$-carotene content ranged from 89.22 to 134.29 for " $\mathrm{T}_{c}$ ", 45.70 to 117.56 for " $\mathrm{T}_{1}$ " and 75.10 to $117.04 \mu \mathrm{g} / \mathrm{g}$ fresh peels for " $\mathrm{T}_{2}$ " treatment. As for the later storage period (from day 20 to day 30 ), the corresponding ranges respectively were from 140.47 to $147.30,147.31$ to 151.35 and 150.97 to $152.12 \mu \mathrm{g} / \mathrm{g}$ fresh peels.

Table (9): Effect of pre-harvest spray of mango trees cultivars Hindi and Zibda with 2 various antioxidant solutions on changes in total chlorophylls content in fruit fresh peels at harvest time (0) and 5-day-intervals during cold storage period at $5 \pm 1^{\circ} \mathrm{C}$ for 30 days.

\begin{tabular}{|c|c|c|c|c|c|c|c|c|c|}
\hline \multirow{2}{*}{\multicolumn{2}{|c|}{ Cultivar }} & \multirow{2}{*}{$\begin{array}{c}\text { Sym } \\
- \\
\text { bol }\end{array}$} & \multicolumn{7}{|c|}{$\begin{array}{l}\text { Total chlorophyll content in fruit fresh peels during storage in } \\
\text { days }(\mu \mathrm{g} / \mathrm{g} \text { peels })\end{array}$} \\
\hline & & & 0 & 5 & 10 & 15 & 20 & 25 & 30 \\
\hline \multicolumn{2}{|c|}{ Hindi } & & $382.29^{*}$ & 317.97 & 250.79 & 239.07 & 225.74 & 192.88 & 173.96 \\
\hline \multicolumn{2}{|c|}{ Zibda } & & 428.89 & 406.28 & 385.62 & 359.79 & 338.28 & 319.74 & 299.39 \\
\hline \multicolumn{2}{|c|}{$\mathrm{F}$ test } & & $* *$ & $\star *$ & ** & $\star *$ & $\star *$ & $* *$ & $* *$ \\
\hline \multicolumn{10}{|c|}{ Treatments } \\
\hline \multicolumn{2}{|c|}{ Water (control) } & $T_{c}$ & $411.14^{*}$ & 375.78 & 340.47 & 315.41 & 295.09 & 270.76 & 249.38 \\
\hline \multicolumn{2}{|c|}{ VitC $1.0 \mathrm{gL}^{-1}$} & $T_{1}$ & 385.12 & 350.45 & 302.36 & 292.15 & 276.70 & 264.28 & 253.13 \\
\hline \multirow{2}{*}{\multicolumn{2}{|c|}{$\frac{\text { Vit }_{\mathrm{B} 12} 1.0 \mathrm{mgL}^{-1}}{\text { L.S.D } 5 \%}$}} & $\mathrm{~T}_{2}$ & 420.82 & 360.15 & 311.79 & 290.73 & 274.25 & 233.89 & 207.51 \\
\hline & & & 6.95 & 2.36 & 6.47 & 5.42 & 6.08 & 4.49 & 4.44 \\
\hline Cultivar & Treatments & & & & & & & & \\
\hline \multirow{3}{*}{ Hindi } & $\begin{array}{c}\text { Water } \\
\text { (control) }\end{array}$ & $\mathrm{T}_{\mathrm{c}}$ & $363.28^{*}$ & 319.72 & 280.80 & 259.53 & 239.38 & 222.78 & 197.73 \\
\hline & VitC $1.0 \mathrm{gL}^{-1}$ & $\overline{T_{1}}$ & 360.90 & 310.61 & 235.02 & 230.24 & 218.53 & 204.72 & 200.56 \\
\hline & $\begin{array}{c}\mathrm{Vit}_{\mathrm{B} 12} \\
1.0 \mathrm{mgL}^{-1}\end{array}$ & $\mathrm{~T}_{2}$ & 422.70 & 323.58 & 236.55 & 227.44 & 219.31 & 151.14 & 123.59 \\
\hline \multirow{3}{*}{ Zibda } & $\begin{array}{c}\text { Water } \\
\text { (control) }\end{array}$ & $\mathrm{T}_{\mathrm{c}}$ & 459.00 & 431.84 & 400.14 & 371.30 & 350.80 & 318.74 & 301.04 \\
\hline & VitC $1.0 \mathrm{gL}^{-1}$ & $\mathrm{~T}_{1}$ & 409.34 & 390.29 & 369.70 & 354.05 & 334.86 & 323.83 & 305.71 \\
\hline & $\begin{array}{c}\mathrm{Vit}_{\mathrm{B} 12} \\
1.0 \mathrm{mg}^{-1}\end{array}$ & $\mathrm{~T}_{2}$ & 418.35 & 396.72 & 387.03 & 354.01 & 329.19 & 316.64 & 291.42 \\
\hline \multicolumn{2}{|c|}{ L.S.D 5\% } & & 7.70 & 9.19 & 6.22 & 5.50 & 6.45 & 4.71 & 4.93 \\
\hline
\end{tabular}

${ }^{*}$ These values represent the average results of 2008 and 2009 seasons.

Concerning the results of fresh peels total chlorophylls, the listed data in Table (9) cleared a significant effect of the cultivar and treatment tested on this pigment contents in fresh peels of both "Hindi" and "Zibda" fruits. At harvest time, the concerned results once more proved that among the examined treatments vitamin $B_{12}$ was the best treatment to produce "Hindi" fruits significantly contained the highest chlorophylls value in fruit fresh peels $\left(422.70 \mu \mathrm{g} / \mathrm{g}\right.$ fresh peels) if compared to those of " $\mathrm{T}_{1}$ " (360.90) and " $\mathrm{T}_{c}$ " (363.28) fruits. The difference between the determined values for the last two inferior treatments in that respect was insignificant. As for "Zibda" treated 
fruits, trees under the antioxidant treatments produced at harvest time fruits contained chlorophylls content significantly lower than that in the control fruit peels. The tabulated chlorophyll average values for fruit peels of " $\mathrm{T}_{1}$ " and " $\mathrm{T}_{2}$ " treatments, respectively were 409.34 and $418.35 \mu \mathrm{g} / \mathrm{g}$ fresh peels compared with $459.00 \mu \mathrm{g} / \mathrm{g}$ fresh peels in the control fruit fresh peels.

Concerning changes in peel chlorophylls content during cold storage period, the periodical determinations as presented in the same table showed an obvious decrease due to the tested treatments as the storage period advanced. The rate of decrease differed among the tested treatments. The most effective treatment to decrease peel chlorophylls content of both cultivars was " $\mathrm{T}_{2}$ " treatment, since its fruits at the last periodical determination achieved the average values 123.59 and $291.42 \mu \mathrm{g} / \mathrm{g}$ fresh peels for "Hindi" and "Zibda" cultivars, respectively. The corresponding average values in fruit peels of " $\mathrm{T}_{1}$ " and " $\mathrm{T}_{\mathrm{c}}$ " treatments, respectively were 200.56 and $197.73 \mu \mathrm{g} / \mathrm{g}$ fresh peels for "Hindi" stored fruits along with 305.71 and $301.04 \mu \mathrm{g} / \mathrm{g}$ fresh peels for "Zibda" stored fruits.

The gradual increase on $\beta$-carotene content as well as the gradual decrease on chlorophylls content in fresh peels of stored fruits of both mango cultivars during cold storage period are considered a normal incidence. This behavior of both pigments during storage period was in harmony with the statement of Rathore et al., (2007) who indicated that the loss of green color was the most obvious change in mango, which was probably due to the physic-chemical changes by degradation of the chlorophyll structure and increased in carotene pigments during storage. Therefore, we suggest that the active role of the tested antioxidants in that respect is to make these physic-chemical changes more rapid and effective.

The obtained results in the current investigation due to the effects of pre-harvest antioxidant and post-harvest cold storage treatments cleared that the behavior of all the tested characteristics, except changes in fruit weight loss $\%$, at harvest time and during cold storage period were significantly affected by two main factors, cultivar and treatment or both. This variation was previously confirmed in the study of Solomon et al., (2006) who worked with six commercial fig varieties and found that among the tested varieties fruits of the mission variety exhibited the highest antioxidants capacity. They attributed such variation to the different pulp components in fruits which have a positive correlation to the degree of ripeness and hence softness of the pericarp. The positive effect of antioxidants in the current study can be attributed to an increase in antioxidant capacity in stored fruits of both cultivars with a pronounced superiority to vitamin $C$ treatment on some characteristics and vitamin $B_{12}$ one on others of mango cultivars under study at harvest time. Changes on these characteristics during cold storage proved that vitamin C treatment can extend shelf life of "Hindi" and "Zibda" stored fruits till 20 day at the storage conditions. This result is in harmony with the statement of Srilaong and Tatsumi (2003) who reported that vitamin C and phenols are considered of high antioxidant capacity and such activity decreased as the fruit senescence advanced. Ascorbic acid activity was also the aim of studies carried out by Smirnoff (1996); Lee and Kader (2000). They indicated that this vitamin in plants plays a protective role against reactive oxygen process that is formed from photosynthetic and respiratory 
processes. Also, it is linked to cell during growth and division along with acting as a co-factor for many enzymes. In the same subject with Lychee fruits, Terdbaramee et al., (2006) found that post-harvest treated fruits with ascorbic acid at certain concentrations reduced the incidence of browning. The same treatment also caused a decrease on ethylene production and weight loss. Moreover, the storage life of fruits was extended to 28 days. The tabulated results also indicated that vitamin $B_{12}$ treatment relatively could extend shelf life of "Zibda" fruits till the end of cold storage period with mild chilling injury symptoms. The importance of this antioxidant in that respect can be explained from previous statements pointed to the role of vitamin $B_{12}$ for characterization of methionine-synthase enzyme which is required in all organisms for large number of biological substances including the de novo biosynthesis of amino acid methionine. Methionine is the only sulfur containing amino acids that support additional roles than simply serving as a building block for protein synthesis. It is the immediate precursor of a compound plays numerous roles in transmethylation reactions and intermediate in the biosynthesis of polyamines and the phytohormone ethylene. Also this compound via an as yet fully understood link with plant growth hormones such as cytokinins and auxins (ELchel et al., 1995 and Ravanel et al., 1998).

Therefore, pre-harvest spray with antioxidant solutions at a proper concentration is a promising application on mango trees to harvest fruits of acceptable quality to consumers and to optimize shelf life stability of fresh mango fruits for good distribution. This is of great economic value since it reduces the cost of higher profits for growers and marketers through increasing their income. Further studies are needed on this subject not only on mango trees but also can be extended to trees of other fruit crops using more antioxidant compounds and concentrations.

\section{REFERENCES}

Anonymous (2008). The cultivated are of mango in Egypt. Statistical report, Ministry of Agriculture, Egypt.

AOAC (1985). Official methods of analysis of association of official analytical. $14^{\text {th }}$ Ed. Published by AOAC., Washington D. C., USA,pp.832.

Arafat, L. A. (2009). Ascorbic acid and tissue browning in mango cv. Hindi fruits (Mangifera indica L.) under cold storage. J. Agric. Sci. Mansoura Univ., 34(12): 11301-11310.

Award, M. A.; De Jager, A.; Van Derplas, L. H. W. ; Van Derkrol, A. R. (2001). Flavonoid and chlorogenic acid changes in skin of Elstar and Jonagold apples during development and ripening. J. Sci. Hort., 90: 69-83.

Ben-Yehoshua, S.; Shapiro, B.; Chen, Z. E. and Lurie, S. (1983). Mode of action of plastic film in extending life of lemon and bell pepper fruits by alleviation of water stress. Plant Physiol., 73: 87-93.

Coao, S. F.; Zheng, Y. H.; Wang, K.; Jin, P. and Rui, H. (2009). Methyl jasmonate reduces chilling injury and enhances antioxidant enzyme activity in post-harvest loquat fruit. Food Chemistry,115:1458-1463. 
Chaplin, G. R.; Cole, S. R.; Landrin, M.; Nuevo, P. A.; Lam, P. F. and Graham, G. (1991). Chilling injury and storage of mango (Mangifera indica L.) held under low temperatures. Acta Horticulture, 291: 461471.

Connor, A. M.; Luby, J. J.; Hancock, J. M.; Berkheimer, S.; Hansen, E. J. (2002). Changes in fruit antioxidant activity among blueberry cultivars during cold temperature storage. J. Agric. Food Chem., 50:893-898.

Elchel,J.; Gonzalez, J.C.; Hotze, M.;Matthews, R.G.and Schroder,J.(1995).Vitamin-B ${ }_{12}$-independent methionine synthase from a higher plant (Catharanthus roseus)molecular characterization, regulation, heterologous expression, and enzyme properties. Eur.J.Biochem.,23:1053-1058.

Gonzalez-Aguilar, G. A.; Buta, J. G. and Wang, C .Y. (2001). Methyl reduces chilling injury symptoms and enhances colour development of "Kent" mangoes. J. Sci .Food Agric., 81: 1244-1249.

Heyes, J. A.; Blaikie, F. H.; Downs, C. G. and Sealey, D. F. (1994). Textural and physiological chnges during pepino (Solanum muricatum Ait) ripening. Sci. Hortic., 58: 1-15

Kajuna, S.; Bilanski, W. T. and Mittal, G. S. (1997). Textural changes of Banana and plantain pulp during ripening. J. Sci. Food Agric., 75: 244250.

Kays, S. J. (1991). Post-harvest phys. Of perishable plant products. Vas Nostrand Rein Hold Book, AVI Publishing Co, pp: 149-316.

Kittur, F. S.; Saroja, N.; Habibunnisa and Tharanathan, R. N. (2001). Polysaccharide-based composite coating formulations for shelf-life extension of fresh banana and mango. Eur. Food Res. Tec., 213: 306311.

Kondo, S.; Jitratham, A.; Kittikorn, M. and Kanlayanarat, S. (2004). Relationships between jasmonates and chilling injury in mangosteens are affected by spermine. Hort. Sci., 39: 1346-1348.

Kondo, S.; Tsuda, K.; Muto, N. and Ueda, J. (2002). Antioxidative activity of apple skin or flesh extracts associated with fruit development on selected apple cultivars. Scientia Hort., 96: 177-185.

Lee, S. K. and Kader, A. A. (2000). Pre-harvest and post-harvest factor, Linfluencing vitamin $\mathrm{C}$ content of horticultural crops. Post-harvest Biology and Technology, 20: 207-220.

Lim, Y. Y.; Lim, T. T. and Tee, J. J. (2006). Antioxidant properties of Guava Fruit: comparison with some local fruits. Sunway Academic Journal, 3: 9-20.

Medlicott, A. P. and Thompson, A. K. (1985). Analysis of sugar and organic acid in ripening mango fruits (Mangifera indica $L$.) by high performance liquid chromatography. J. Sci. Food Agric., 36: 561-566.

Mohamed, M. and Brecht, J. K. (2002). Reduction of chilling injury in (Tommy Atkins) mangoes during ripening. Scientia Horticulture, 95: 297-308.

Moran, R. (1982). Formulae for determination of chlorophyllous pigments extracted with N, N-Dimethylformamide. Plant Physiol., 69: 1376-1381.

Paull, E. R. (1999). Effect of temperature and relative humidity on fresh commodity quality-post-harvest Biol. Technol.,15: 263-277. 
Peter, M. ; Leonard, F. ; Bernard,C. ; Joyce,K.; Victor,G . and Kaswija, M. (2007). Physical and chemical characteristics of off vine ripened mango (Mangifera indica L.)fruit (Dodo).African Journal of Biotechnology, 6 (21):2477-2483.

Ranganna, S. (1979). Manual of analysis of fruit and vegetable products. $2^{\text {nd }}$ Ed. Tata Mcgraw. Hill, publishing company Limited, New Delhi, pp. 634.

Rathore, H. A.; Masud, T.; Sammi, S. and Soomro, H. A. (2007). Effect of storage on physico-chemical composition and sensory properties of mango (Mangifera indica L.) variety Dosehari. Pakistan Journal of Nutrition ,6(2): 143-148.

Ravanel, S.; B. Gakiere; D. Job and Douce, R. (1998). The specific features of methionine biosynthesis and metabolism in plants. Proc. Nath. Acad.Sci., 95: 7805-7812 USA

Reyes, M. U. and Paull, R. E. (1995). Effect of storage temperature and ethylene treatment on guava (Psidium guajava L.) fruit ripening. Postharvest Biol. and Technol., 6: 357-365.

SAS (1996). Users Guide: Statistics, version 5 Ed. SAS Institute, Inc. Cary, NC, USA.

Sauco, V.G. (2002). Magazine of chronic a Horticulture int. Soc. Hort. Sci., 42: $14-17$.

Smirnoff, N. (1996). The function and metabolism of ascorbic acid in plants. Ann. Bot., 78:661 -669.

Solomon, A.; Golubowicz, S.; Yablowicz, Z.; Grossman, S.; Bergma, M.; Gottlieb, H. E.; Altman, A.; Kerem, Z. and Flaishman, M. A. (2006). Antioxidant activities and anthocyanin content of fresh fruits of common fig (Ficus carica L.). J. Agr. Food Chem., 54: 7717-7723.

Srilaong, V. and Tatsumi, Y. (2003). Changes in respiratory and antioxidative parameters in cucumber fruit (Cucumis sativus L.) stored under high and low oxygen concentration. J. Jpn. Soc. Hort. Sci., 72:525-532.

Suwapanich, R. and Haewsungcharoen, M. (2007). Effect of temperature on thermal Properties of mango Nam Dok Mai cv. Si thong during storage. Journal of Agricultural Technology, 3(1): 137-142.

Tasneem, A. (2004). Post-harvest treatments to reduce chilling injury symptoms in stored mangoes .M.Sc. Thesis, Macdonald campus of University, Canada.

Terdbaramee, U.; Ratana khanokchai, K.; Kanlavanarat, S. (2006). Control of post-harvest browning of lychee fruit using ascorbic acid. Acta Horticulture, 712:687-692.

Wolfe, K.; Wu, X. and Liu, R. H. (2003). Antioxidant activity of apple peels. J. Agric. Food Chem., 51: 609-614.

Zhao, Z.; Cao, J.; Jiang, W.; Gu, Y. and Zhao, Y. (2009). Maturity-related chilling tolerance in mango fruit and the antioxidant capacity involved. Journal of the Science of Food and Agriculture, 89(2): 304-309.

Zheng, W. and Wang, S. Y. (2003). Oxygen radical absorbing capacity of phenolics in blueberries, cranberries, chokeberries, and lingonberries. J. Agric. Food Chem., 51: 502-509. 


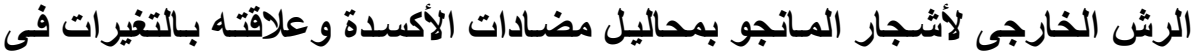

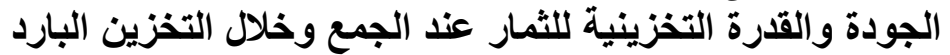

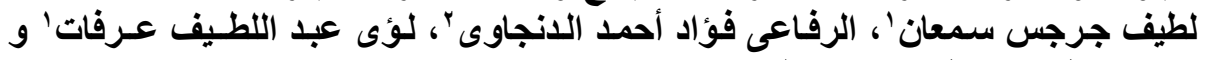

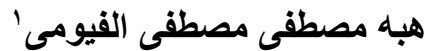

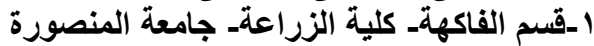 r-قسم الفاكهة. كلية الزراعة. فرع دمياطـ جامعة المنصورة}

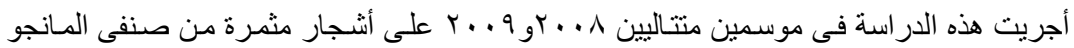

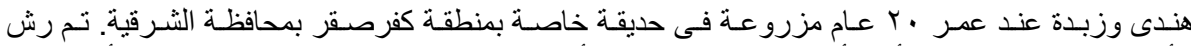

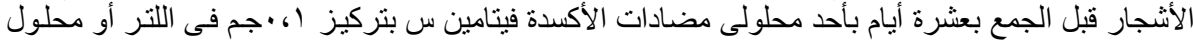

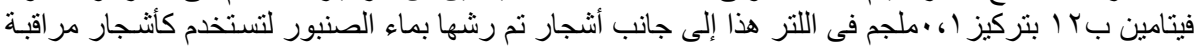

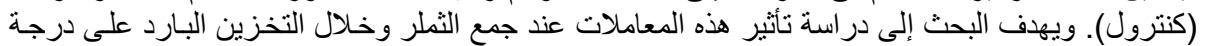

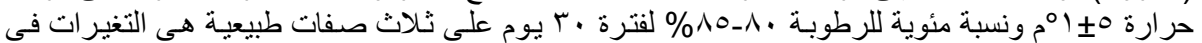

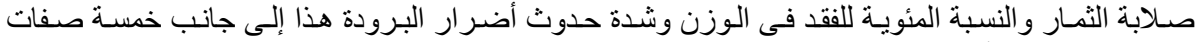

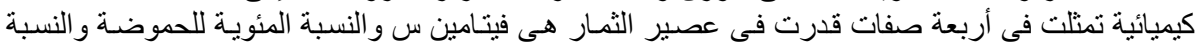

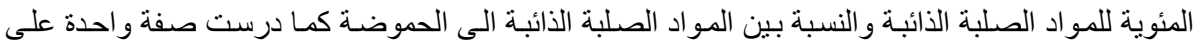

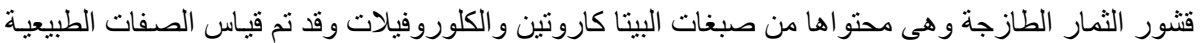

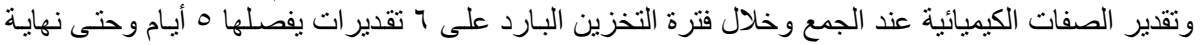
فترة التخزين.

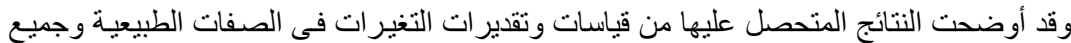

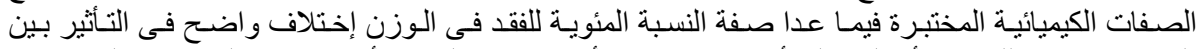

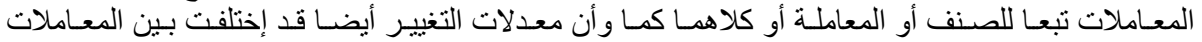

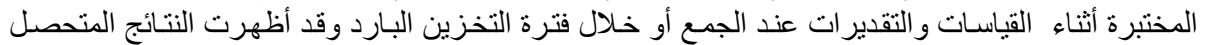

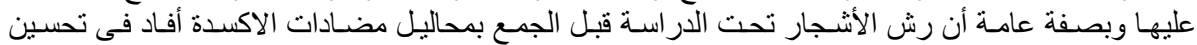

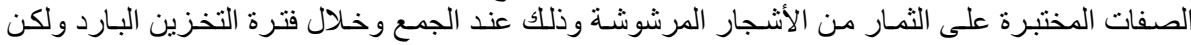

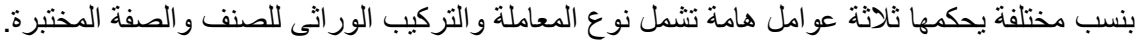

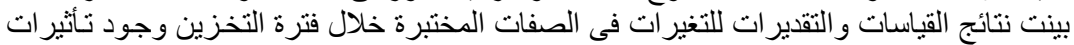

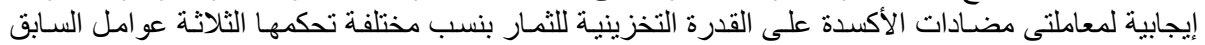

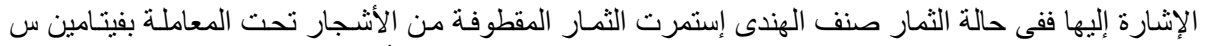

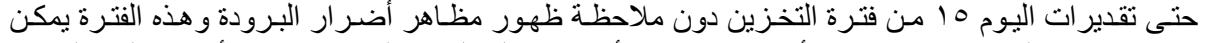

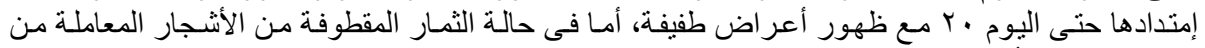

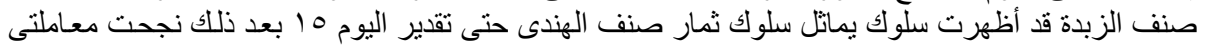

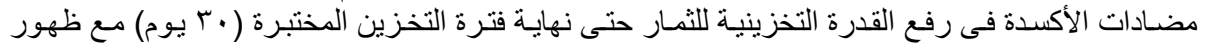

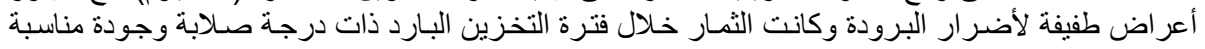

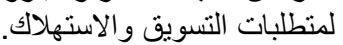

كلية الزراعة - جامعة المنصورة كلية الزراعة بمشتهز - جامعة بنها
قام بتحكيم البحث

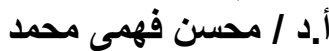

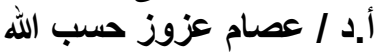

